\title{
SECTION 22(d) OF THE INVESTMENT COMPANY ACT OF 1940-ITS ORIGINAL PURPOSE AND PRESENT FUNCTION
}

\author{
JAMES V. HEFFERNAN* AND JAMES F. JORDEN**
}

The implementation of section 22(d) of the Investment Company Act of 1940 has resulted in a form of retall price maintenance in the mutual fund industry. The justification for this anti-competitive situation has largely rested on the assumption that section 22(d) was intended to eliminate price discrimination as between general members of the purchasing public. In this article Messrs. Heffernan and Jorden carefully examine the legislative history of section $22(d)$ and conclude that the section was aimed, not at price discrimination in the above sense, but at value dilution abuses resulting from riskless trading on the part of dealers, distributors and mutual fund insiders. Finding that the specific abuses to which section $22(d)$ was initially addressed have been eliminated by other means, the authors suggest that considerations of the future role of 22(d) (whether in the context of an attempt to repeal or simply an application for exemption) should reflect this historical perspective.

Since the passage of the Investment Coinpany Act of 1940 ("1940 Act"), ${ }^{1}$ section $22(d)^{2}$ of that Act has been the subject of

* A.B., 1949; J.D., 1952, Cornell University; Member of the D.C., Maryland Bars; Partner, Sutherland, Asbill \& Brennan, Washington, D.C.

*** A.B., 1963, Dickinson College; LL.B., 1966, George Washington University; Member of D.C., Virginia Bars; Partner, Sutherland, Asbill \& Brennan, Washington, D.C.

1. 15 U.S.C. $\$ \S 80 \mathrm{a}-1$ to $-52(1970)$. The 1940 Act provides that an issuer which comes within any of three categories shall be deemed an "investment company": (1) any issuer which "is or holds itself out as being engaged primarily, or proposes to engage primarily, in the business of investing, reinvesting, or trading in securities," id., $\$ 80 \mathrm{a}-3$ (a)(1); (2) any issuer which "is engaged or proposes to engage in the business of issuing face amount certificates of the installment type, or has been engaged in such business and has any such certificate outstanding," id. \& 80a-3(a)(2); or (3) any issuer which "is engaged or proposes to engage in the business of investing, reinvestimg, owning, holding, or trading in securities, and owns or proposes to acquire investment securities having a value exceeding 40 percentum of the value of such issuer's total assets (exclusive of Government securities and cash items) on a consolidated basis," id. $\$ 80 \mathrm{a}-3(\mathrm{a})(3)$.

"Investment companies" may be subdivided into, inter alia, two distinct types: (1) "open-end" companies, commonly referred to as "mutual funds," which stand at all times ready to redeem their issued stock at net asset value; and (2) "closed-end" companies, which do not offer this ready redeniption feature. See R. JENNINGs \& H. Marsh, CaSes and Materials on Securities Regulation 1441-42 (3d ed. 1972).

The basic purpose of the 1940 Act was to protect the "public interest" and "interest of investors" by requiring full and fair disclosure "concerning the character of [imvestment company] securities and the circumstances, policies, and financial responsibility of such companies and their management," 15 U.S.C. \& 80a-1(b)(1); and 
much comment. ${ }^{3}$ Whatever its original purpose, that provision has been applied by the Securities and Exchange Commission (SEC) to impose what amounts to retail price maimtenance on the sale of mutual fund shares. Literally, section $22(d)$ only requires that mutual fund shares be sold to the public at "a current public offering price described in the prospectus," 4 but in general it has been construed to mean that the price must be the same for all investors.

The objectionable features of sucl retail price maintenance are found only in the sale of securities issued by "load funds"- that is, those mutual funds in which the price of the fund's shares is the net asset value per share of the fund plus a sales charge, or load, added thereto. ${ }^{5}$ Funds which impose a sales load are permitted, pur-

by preventing the operation and management of such companies, and the selection of their portfolio securities, in the interests of various insiders, affiliated persons, underwriters, brokers, or dealers-"rather than in the interests of all classes of such companies' security holders." Id. $\$ 80 \mathrm{a}-1$ (b)(2).

HEREINAFTER THE FOLLOWING CITATIONS WILL BE USED IN THIS ARTICLE:

SEC, Report on Investment Trusts and Investment Companies, pt. III (1940) [hereinafter cited as Investment Trust Study];

House COMM. ON INTERSTATE AND FOREIGN COMMERCE, REPORT OF THE SEC ON the Public Policy Implications of Investment Company Growth, H.R. Rep. No. 2337, 89th Cong., 2d Sess. (1966) [hereinafter cited as PubLIc Policy Study];

Hearings on S. 1659 Before the Sen. Comm. on Banking and Currency, 90th Cong., 1st Sess. (1967) [hereinafter cited as $S .1659$ Hearings];

Hearings on H.R. 10065 Before the House Comm. on Interstate and Foreign

Commerce, 76th Cong., 3d Sess. (1940) [heremafter cited as 1940 Act House Hearings]; Hearings on S. 3580 Before a Subcomm. of the Senate Comm. on Banking and Currency, 76th Cong., 3d Sess. (1940) [hereinafter cited as 1940 Act Senate Hearings]; The Mutual Fund Industry: A Legal Survey, 44 Notre Dame Law. 732 (1969) [heremafter cited as Mutual Fund Survey].

2. 15 U.S.C. $\$ 80 \mathrm{a}-22$ (d) (1970).

3. See sources cited note 10 infra; Hodes, Current Developments Under Section 22(d) of the Investment Company Act, 13 B.C. IND. \& CoM. L. Rev. 1061 (1972).

4. No registered investment company shall sell any redeemable security issued by it to any person except either to or through a principal underwriter for distribution or at a current public offering price described in the prospectus, and, if such class of security is being currently offered to the public by or through an underwriter, no principal underwriter of such security and no dealer shall sell any such security to any person except a dealer, a principal underwriter, or the issuer, except at a current public offering price described in the prospectus. . . I I U.S.C. \& 80a-22(d) (1970).

5. See id. $\$ 80 \mathrm{a}-22(\mathrm{a})$ to $-22(\mathrm{c})$. A "sales load" is defined in $\$ 80 \mathrm{a}-2(\mathrm{a})(35)$ of the Act as

[T] tion of the proceeds from its sale which is received and invested or held for investment by the issuer . . . less any portion of such difference deducted for trustee's or custodian's fees, imsurance premiums, issue taxes, or administrative expenses or fees which are not properly chargeable to sales or promotional activities....

While there are "no load" mutual funds, virtually all open-end companies having a sales force impose a sales load. See Mutual Fund Survey 744, 833, 843. Closed- 
suant to SEC rule 22d-1 under the $1940 \mathrm{Act}^{\text {" }}$ to have a "scale" of sales loads which decreases as the amount of securities purchased increases $;^{7}$ but, with certain limited exceptions, ${ }^{8}$ the same sales load must be applied to purchases by all investors who purchase an equal number of shares, so that there is a resulting uniformity in the public offering price. Thus, even if an investor has decided to purchase a particular mutual fund's shares without having been exposed to any sales effort by any salesman, he inust still pay a sales charge "designed to cover selling efforts that he does not want, does not need, and does not get."9

Almost all who have written about section 22(d) of the 1940 Act have contended that the reasons behind its enactment were not articulated at the congressional hearings or in the committee reports, and that neither of these sources contain any legislative history of any value. ${ }^{10}$ Arguments have raged from all sides as to the propriety of such a retail price maintenance provision, ${ }^{11}$ but there has been

end companies do not impose a sales load on the price of their shares, but the purchaser usually pays a somewhat lower sales fee in the form of a brokerage commission. Id. at 744 .

6. 17 C.F.R. $\$ 270.22 \mathrm{~d}-1$ (1972).

7. Rule 22d-1(a), 17 C.F.R. § 270.22d-1(a) (1972), authorizes a scale of reducing sales loads to be computed on any of three bases: the quantity of securities purchased at any one time; the total quantity of securities purchased dnring a 13month period; or the aggregate quantity of securities previously purchased and then owned plus the securities being purchased.

8. Reduced sales loads are also permitted under rule 22d-1, supra note 6, for plans providing for reinvestment of income and capital gains distributions; upon the sale to certain qualified plans under INT. REv. CODE of 1954, section 401; upon the sale to registered unit investment trusts; for private offerings in connection with the organization of the issuer; and upon the sale to "directors, officers or partners of the investment company, its investment adviser or principal underwriter, or to the bona fide, full-time employees or sales representatives of any of the foregoing," provided such purchases are made for investment. Id. \$ 270.22d-1(b)-(h). A fairly recent amendment to this portion of the rule limits the latter sales to persons who spend at least one half of their working time performing certain services for the mutual fund or its investment adviser. Rule 22d-1(h), id. $\$ 270.22 d-1(h)$ (1972), promulgated by SEC Investment Company Act Release No. 6347 (Feb. 8, 1971).

9. Public Policy STUdy 221.

10. See, e.g., Greene, The Uniform Offering Price of Mutual Fund Shares Under the Investment Company Act of 1940, 37 U. DET. L.J. 369, 371 (1960); Simpson \& Hodes, The Continuing Controversy Surrounding the Uniform Price Maintenance Provisions of the Investment Company Act of 1940, 44 Notre DAME LAw. 718, 719 (1969). The SEC itself has adopted these assertions. See PUBLIC Policy STUdy 219.

11. For a defense of the continued necessity for the provision, see Simpson \& Hodes, supra note 10, at 731 , and Statement of Investment Company Institute, $S$. 1659 Hearings 320. For countervailing arguments see PUBLIC PoLICY STUDY 217. See also Statement of Professor Irwin Friend, in S. 1659 Hearings 665; Mutual Fund Survey 838. 
a general acceptance of what, somewhere along the line, have developed to be standard assertions as to the historical derivation and "purposes" of section 22(d). Briefly, these assertions are as follows:

(1) That the provision was drafted by the investment company industry rather than by the SEC and was inserted into the statute at the industry's request (thus implying that there would be little possibility for any "legislative history" simce the SEC never contemplated such a provision);

(2) That the objectives of the section were "well known to the industry and the Commission" and were as follows:

(a) To insure orderly distribution in the marketing of mutual fund shares.

(b) To prevent discrimination or preferential treatment in price among buyers.

(c) To prevent sales of mutual fund shares via "third markets" or "bootleg markets" established by dealers who had not contracted with the issuing investment company for the sale of its shares (non-contract dealers)..$^{12}$

In this article, we intend to develop a second (or first) look at section 22(d) as an integral part of the overall scheme of section 22 of the 1940 Act. We believe there is some question as to the continued validity of the above assertions in view of what the legislative history of the 1940 Act actually discloses as to the background and purpose of section 22(d). That history, as will be discussed below, reveals that the requirement of a uniform sales load was a compromise provision designed primarily as a device to curb abuses resulting in dilution of the value of mutual fund shares and, possibly, to impose some limitations on the activities of "non-contract" dealers. ${ }^{13}$ Only incidentally, and as a natural consequence of its operation, did the section entail the "price-fixing" aspects which are now assuned by many to be its raison d'etre.

12. See Greene, supra note 10, at 372. The "bootleg market" was a pre-1940 Act market maintained by non-contract dealers who did not have to give up any portion of the sales load to the princjpal underwriter and, therefore, could ask less than the nornal sales price and still get a greater profit spread than the authorized dealer.

13. The extent to which section $22(d)$ in fact was interided to control the activities of selling brokers and dealers is presently being litigated in several antitrust suits. (See note 129 infra and áccompanying text.) While some writers have at least implied that the written record may not completely reflect the intent of Congress, this Article will focus almost exclusively on the Investment Trust Study and the Senate and House hearings. 
Renewed scrutiny of the circumstances which actually generated the passage of section 22(d) seems especially appropriate in view of the current controversy regarding the desirability of continuing the retail price maintenance structure which has resulted from that section's enactment. ${ }^{14}$ Our purpose, therefore, is to examine whether, in light of subsequent developinents, section 22(d), as presently construed and applied, continues to be necessary to curb the specific abuses to which it was initially addressed.

\section{Legislative History of Section 22(d)}

\section{Investment Trust Study}

The Report on Investment Trusts and Investment Coinpanies ${ }^{15}$ was prepared by the SEC pursuant to the direction of section 30 of the Public Utility Holding Coinpany Act of $1935 .^{16}$ In Volume Three of that Report, the SEC discussed in solne detail the abuses then prevalent in the inutual fund trading practices of distributors, dealers and, to some extent, investment company insiders. ${ }^{17}$ Three principal types of abuses, collectively characterized as "trading against the fund," were noted, all of which stemmed from the operation of what has been referred to as the "two-price" system. ${ }^{18}$

To appreciate the developinent of these specific pricing and sales practices, some understanding of the operation of the "two-price" systen is necessary. ${ }^{19}$ The "two-price" system can only prevail where there is "backward pricing;" that is, where the price of the mutual fund shares is based on previously determined values of the underlying assets. When such a pricing structure existed, the investment coinpany's portfolio was norinally valued daily at the close of trading on the New York Stock Excliange. However, the net asset value

14. See text accompanying notes 72-130 infra. In the 91st Congress Senator Mcintyre introduced a bill, S. 296, which provided for the complete repeal of section 22(d). S. 296, 91st Cong., 1st Sess. $\$ 12$ (a) (1969). However, the Investment Company Amendments Act of 1970, Pub. L. No. 91-547, 83 Stat. 1413, as passed, made only certain technical amendments to section 22 (d) leaving the substantive retail price maintenance portion untouched.

15. Investment Trust Study.

16. 15 U.S.C. $\$ 79 z-4$ (1970).

17. Investment Trust Study 855-75. References to "insiders" include officials and employees of the imvestment company, its imvestment adviser and its principal underwriter, and affiliates thereof, and any other persons who could be considered to be in the role of an "insider" as to an investment company. The significant characteristic for our purposes is that these people in many cases were able to buy shares of a "load" fund without paying the standard sales commission.

18. $I d$.

19. For a shorthand example of this system see Mutual Fund Survey 790-92. 
price for the fund's shares based on that day's valuation did not go into effect until the opening of the Exchange the following inorning. In the interim period (i.e., between the close of the New York Stock Exchange on one day and the opening of the Exchange the next day), two prices could be ascertained-the present trading day's price, which was coinputed on the preceding day's asset values and which was still in effect, and the price for the next trading day which had been conputed on the present day's asset values but which had not as yet gone into effect. Thus, if an investment coinpany's net asset value as of the close of the Exchange on a given trading day had increased over its net asset value at the close of the Exchange on the preceding day, a purchaser could buy into the fund at a price which was lower than the current net asset value-because the price based on that value had not yet gone into effect. ${ }^{20}$ For example, suppose $A B C$ Fund values its portfoho on December 1 at the close of business of the New York Stock Exchange ( 4 p.in.) and this results in a valuation of $\$ 11$ per share net asset value. That is the price of the shares all during the day of December 2, even if the value of the portfolio for $A B C$ has substantially increased during the day. At 4 p.m., the portfolio is valued and the per-share net asset value is now $\$ 11.20$ (which is an exaggeration for the purpose of illustration simce such a substantial increase is unlikely to occur in one day's trading in a mutual fund of any size). At this point, two prices are in effect: (1) $\$ 11$ per share for which the shares may be bought; and (2) $\$ 11.20$ per share for which the shares bought at $\$ 11$ can be sold on December 3, the next day. The vulnerability of such a system to value-diluting in-and-out transactions is readily apparent. ${ }^{21}$

A form of backward pricing continued to exist in the industry until 1968, when the SEC adopted rule $22 \mathrm{c}-1 .^{22}$ That rule required

20. For the average investor, who was required to purchase shares at the full sales load, it would not normally be profitable to buy and sell immediately in a rising market, since the one-day increase would usually be too small to offset the load he would have to pay on the purchase. However, insiders, who were not required to pay the full load (or any at all) and who were aware of the two prices, could buy at the lower price, hold for one day, and then redeem the shares at the higher price the next day. See 1940 Act Senate Hearings 142, 842. In addition to using the investing technique noted above, dealers could profit through this two-price system by acquiring shares at the lower of the two known prices with a view to using shares the next day to fill orders at the higher price. Thus, the dealer would retain tho balance between the two prices, in addition to the increased sales load on the next day's higher price. See id. at 144-45.

21. See text accompanying note 31 infra.

22. 17 C.F.R. $\$ 270.22 c-1$ (1972): 
all open-end investment companies to value their shares for purchases and redemptions at the next daily computed net asset value of the fund after receipt of an order to purchase or after the tender of a security for redemption. This form of pricing is known as "forward pricing" or "fixed pricing" and, as poimted out below, had it been adopted at the time of enactment of the 1940 Act, the principal abuses which section 22(d) was designed to curb would have been eliminated and that provision itself would probably not have been enacted, or, if enacted, would have been addressed more specifically to the problems generated by the activities of "non-contract" dealers.

The following three primcipal abuses were focused on in the Investment Trust Study:

\section{(1) Riskless Trading Profits for the Dealer:}

A number of factors operated to provide riskless trading profits for the dealer. In inany cases, contract dealers (dealers authorized to sell investment company shares by contract with the principal underwriter) inventoried stock of the investment company, acting as principal both in the purchase and sale of such stock-in effect establishing a "secondary" market. If the dealer was long in a stock $^{23}$ at a price equal to (or below) current net asset value, upon sale of the stock, he retained the full load paid by the investor (as well as any increase in the price paid by the imvestor over the price of the stock in the dealer's inventory), since the dealer did not have to call upon the distributor to furnish the stock. Thus, because he could ride with a decline in the stock's price until it had offset the amount of the load he could charge when he sold, the dealer was in the uniquely advantageous position of being able to hedge with inventory on a rise in the fund stock's price (with the help of the backward pricing system) while exposing himself to virtually no

(a) No registered investment company issuing any redeemable security, no person designated in such issuer's prospectus as authorized to consummate transactions in any such security, and no principal underwriter of, or dealer in, any such security shall sell, redeem, or repurchase any such security except at a price based on the current net asset value of such security which is next computed after receipt of a tender of such security for redemptions or of an order to purchase or sell such security.

(b) For the purposes of this section, the current net asset value of any such security shall be that computed on each day during which the New York Stock Exchange is open for the trading, not less frequently than once daily as of the time of the close of trading on such Exchange.

23. A dealer who takes a long position buys or contracts to buy a supply of that stock exceeding the amount of the stock for which he has received orders or contracted to deliver, speculating on a significant future advance in the market. BLACK's LAw Dictionary 1092 (rev. 4th ed. 1968). 
risk of loss. Only when, due to the absence of buy orders, he was forced to turn in his inventory to the distributor for redemption or resale at a reduced current asset value would the dealer suffer any loss.

In some circumstances, as where the dealer had purchased the securities of the fund from retiring shareholders at the low bid price, ${ }^{24}$ a dealer could make a profit from his long position even in a declining market by timely hquidation with the distributor. According to the Investment Trust Study, this stemmed from a combination of three factors: First, the distributors' maintenance of an independent market (thus enabling them to repurchase from the dealer at current price) $;{ }^{25}$ second, the fact that the dealer was not required to pay a load (or premium) above the net asset value for the purchase of the shares; and third, the fact that the dealer knew in advance the next day's price. ${ }^{26}$ Thus, in anticipation of a rising market, a dealer might purchase the securities of the fund from a retiring shareholder at the distributor's bid price. If no buy orders materialized after several days of a rising market, and if a dechine in asset value then ocurred (which he would know because of the two-price system), the dealer could hquidate his position with the distributor before the reduction in value affected the price he could get. Profits, of course, were much greater in a constantly rising market. As the Investment Trust Study points out, the public investor was not in a position to obtain similar benefits because, in order to purchase, "he had to pay a premium (or load) over asset or hquidation value, a premium which was lost upon redemption."27

(2) Virtually Riskless Trading Profits for the Principal Distributor:

The principal distributor (principal underwriter), ${ }^{28}$ if permitted by his contract to act as principal in the purchase and sale of shares, often obtained the same riskless trading advantages mentioned above which were available to the dealer, with one exception. In a declin-

24. The bid price represented what the distributor would pay on redemption. Investment Trust Study 861 n.323.

25. See note 28 infra and accompanying text.

26. Investment Trust Study 862.

27. Id.

28. Id. at 864. A "principal underwriter" is defined in section $2(a)(29)$ of the 1940 Act, 15 U.S.C. $\$ 80 \mathrm{a}-2(29)$ (1970). When he acts as principal, he buys mutual fund shares from the fund itself, at no-load, for the purpose of filling dealers' orders for the fund shares daily. He usually maintains a "repurchase" market for the fund shares to afford shareholders and dealers immediate redemption of their shares. 
ing market, the distributor could not obviate the risk of loss on shares purchased in anticipation of buy orders by inerely obtaining the redemption of those shares, unless the investment coinpany redeemed on the basis of the current day's inarket close. Most coinpanies, however, offered shares on the basis of the previous day's close and redeemed shares on the basis of the following day's close.

Thus, while a contract dealer could cover a potential loss in a declining market by obtaining immediate liquidation from the distributor at the current net asset value of the fund (the current bid price inaintained by the distributor), the distributor normally had to wait 24 hours for determination of the investment company's redemption price. However, as stated in the Investment Trust Study, "on a rising nnarket and with no load to overcome, the risk taken by the distributor would be minimized. Furthermore, if the investment company redeemed on the basis of the current day's market close, the risk was eliminated."29

\section{(3) The So-Called "Bootleg" Market:}

This market, mentioned briefly in the Investment Trust Study, was made by dealers who traded in mutual fund shares without the authority of the principal underwriter and therefore without the necessity of surrendering any portion of the sales load. As explained in the Study:

These dealers would often offer a little more than the published redemption price and ask a little less than the published sale price. In an active market, the unauthorized dealer could still get a greater spread than the authorized dealer. ... Such operations actually had the effect of initiating a small scale price war between retailers and tended generally to disrupt the established offering price..$^{30}$

The main emphasis of the Study, however, was on the assetdiluting problems engendered by riskless, or virtually riskless, trading around the backward pricing system rather than on the potential for retail price war anong dealers. The dilution referred to resulted froin the reduction in value of existing shareholders' pro-rata interest in the fund arising as a natural consequence of backward pricing

29. Investment Trust Study at 864.

30. Id. at 865 (citation omitted). This "bootleg" market among non-contract dealers should be distinguished from the secondary market established and maintained by contract dealers, which was apparently a much stronger and much more active market. Id. at 809,857 . As to this latter market, the principal abuse commented upon in the Study was not the disruption of the offering price, but rather the riskless profit which could be obtained by such dealers as a result of the two-price system. 
in a rising market. For example, if yesterday there were 10 shares outstanding and $\$ 100$ in the fund, and today the fund is worth $\$ 110$, one who purchases today under the backward pricing system would pay $\$ 10$ per share rather than $\$ 11$ (which represents the existing shareholders' pro-rata interest in the $\$ 110$ fund). Thus, the $\$ 10$ increase in the fund's value will be diluted to the extent that today's purchaser is permitted to share in that increase by buying at yesterday's price. It was noted in the Study that the incoming shareholder, as well as the distributor and dealer, could benefit from the "price lag" caused by this system. ${ }^{31}$ In addition, dealer and insider purchases, which took advantage of the two-price system and the operation of the purchase and redemption structure in general through "riskless trading" or "trading agamst the trust," increased the shareholders' dilution loss and resulted in unwarranted profits. ${ }^{32}$ There was no mention in the Study, however, of any problems of price "discrimination" resulting from variations in the sales load imposed on the purchase of shares by different members of the general investing public.

\section{Congressional Action}

The text of the congressional hearings on the Investment Company Act of 1940 amounts to some 1,300 pages. The SEC presented the findings of its study at the imitial hearings before a Subcommittee of the Senate Committee on Banking and Currency. ${ }^{33}$ It then gave its recommendations, which had been embodied in proposed bill $\mathrm{S}$. $3580 .^{34}$ At the conclusion of the Commission's testimony, the industry spokesmen stated their positions-in general agreeing with the

31. Id. at 865-66: "Although the informed incoming stockholder could benefit from the operation of the two-price system because he could buy in a rising market at the lower of two prices, the existing stochholder nevertheless sustained a diminution of the asset value of his shares." But see text accompanying note 27 supra.

32. "[O]fficers and directors could buy shares for cash without any premium, and hence were able to take a trading position in a fund they were managing." $I d$. at 871 . It should be noted that the sanctions agaimst insider trading contained in section 16(b) of the Exchange Act, 15 U.S.C. $\$ 78 p(b)$ (1970), have never been made applicable to officers, directors, and $10 \%$ beneficial owners in open-end investment companies. See note 71 infra and accompanying text.

33. 1940 Act Senate Hearings 135-59, 288.

34. 76th Cong., 3d Sess. (1940). S. 3580, the origimal bill proposed by the SEC, did not embody section 22(d) or anything closely resembling it. The need for such a provision became apparent during the hearings on S. 3580 and was explicitly provided for in the meinorandum of agreement between the SEC and the representatives of the industry which developed froin these hearings and which constituted the basic framework of the bill as ultimately structured. 1940 Act House Hearings 96-100. See notes 69-70 infra and accompanying text. See also Greene, supra note 10, at 371. 
need for regulation, but opposing certain portions of the bill. ${ }^{35}$ The industry and the SEC then prepared a joint memorandum of agreement on all of the contested provisions of the bill, in which they included a new section $22 .^{36}$ Later, a joint effort was made to present the bill reflecting the compromise between the industry and the SEC.

Mr. Baldwin Bane, then Director of the SEC Registration Division, and Mr. Mahlon E. Traylor, then President of Massachusetts Distributors, Inc., were the spokesmen for the SEC and the industry, respectively, on the question of regulation of selling practices-those provisions ultimately adopted in sections 22 and 23 of the 1940 Act for "open-end" and "closed-end" investment compamies. Building upon the emphasis supplied by the Investment Trust Study, the testimony of these two individuals stressed the abuses of the distribution and pricing system which resulted in the "dilution" of shareholder interest and riskless profits to the distributors, dealers, and insiders. According to their testimony, the "two-price" system had fostered the exploitative buying and selling practices which gave rise to the pressure for regulation in this area. ${ }^{37}$

With these abuses in mind, the SEC's bill, as introduced by Senator Waguer, provided in section 22(a) for regulation of the "investment company" as well as the "principal underwriter" by requiring both to sell, redeem, and repurchase the imvestment company's securities at a price bearing a particular relation to the current asset value of that security, computed as of such time as the Commission should prescribe. ${ }^{38}$ Section $22(\mathrm{~b})$, as originally proposed, addressed one aspect of the riskless trading mentioned above, and would have precluded underwriters and dealers, in connection with a primary distribution, from purchasmg a security from the issuer or from any underwriter except at the price at which such purchasing underwriter or dealer in turn sold the security less an appropriate commission. ${ }^{39}$ Finally, in section 22(c) of the original bill as introduced, the SEC

35. 1940 Act Senate Hearings 325.

36. 1940 Act House Hearings 99.

37. Thus, in a rising market, when the rise results in an asset increase of the share that is greater than the load that is added to cover sales commissions and profits, a person can buy a security, after the two prices are known and established, at the lower of the two prices and almost immediately turn in the share for redemption for a higher price without any chance or risk of loss; he can't lose. . . . We found in our study for September that some insidersthat is officers of the sponsors, managers and underwriters - took advantage of the two price system to buy shares before the advance price went into operation and then almost immediately redeemed them at the higher known price. 1940 Act Senate Hearings 141-42.

38. S. 3580, 76th Cong., 3d Sess. \& 22(a) (1940).

39. Id. $\$ 22(\mathrm{~b})$. 
was given the power to keep investment companies froin selling their securitites at unconscionable or grossly excessive sales loads. ${ }^{40}$ Specific considerations were provided for determining whether a sales load was unconscionable or grossly excessive. ${ }^{41}$

Nothing approaching the present section 22(d) was contained in S. 3580 as introduced. However, one should note that, as introduced, this bill would have given the Commission the power to eliminate effectively the principal abuses of the distribution system, since the bill gave the SEC the power to eliminate the "price lag" caused by the two-price, backward-pricing system. ${ }^{42}$ The approach in the original bill, unlike the approach in the bill as finally adopted, would not have permitted industry self-regulation. Testimony in the legislative hearings, however, shows that the SEC was willing to present a bill which would mect the industry's desires in terms of industry selfregulation. ${ }^{43}$

David Schenker, Chief Counsel for the Investment Trust Study, presented S. 3580 to the Senate Banking and Currency Committee and discussed each of its provisions. In his discussion of section 22, he stated that it dealt with the problem of dilution of shareholders' interest in open-end companies. ${ }^{44}$ He further stated that:

[T] $f$ the industry has any difficulty with giving the Commission power to formulate rules and regulations, then the Commission is prepared to recommend to the committee a specific provision which in its opinion will meet that situation.

We talked to the industry; we had the feeling, although our plan to meet that situation is at least theoretically perfect, they say it may have some nndesirable consequences in connection with their

40. Id. $\S 22(\mathrm{c})$.

41. Id. The bill provided as follows:

In determining whether a sales load is unconscionable or grossly excessive, due weight shall be given to the incidents, denominations, and selling price of the securities imvolved, to the organization, investment policy, past and prospective earnings, management expenses, and management and sales methods of the issuer, its managers, depositors, underwriters, and dealers and its and their competitors, and to such other factors as are relevant in the particular proceeding.

42. The actual pricing system to be established under section 22(a) was not set out. However, by regulating the investment company itself, not just the dealer, some system, such as forward pricing, could be devised to curtail all dilution. To provide against "riskless trading" and "position-taking" by dealers, section 22(b) of that bill contained purchase requirements on the underwriter and distributor. In point of fact, as discussed below, the SEC apparently intended to adopt "forward pricing."

43. See text accompanying note 45 infra.

44. Mr. Schenker stated: "Section 22 deals with the problem which Mr. Bane discussed in detail-that is, the possible dilution of the equity of certificate holders in open-end companies." 1940 Act Senate Hearings 288. 
distribution activities. ${ }^{45}$

Mr. Schenker then referred to Mr. Bane's earlier testimony on industry abuses as a detailed discussion of the subject which section 22 was designed to cover. ${ }^{46}$ Significantly, there is nothing in Mr. Bane's testimony relating to "price discrimination" (i.e., selling identical securities to competing purchasers at different prices), ${ }^{47}$ orderly distribution, or "bootlegging" operations. ${ }^{48}$ To the contrary, Mr. Bane's testimony is almost exclusively taken up with riskless trading and dilution caused by the two-price system.

Mr. Traylor spoke for the industry in response to the testimony of Mr. Bane and Mr. Schenker. ${ }^{49}$ During his testimony, Mr. Traylor stated that at first the industry liad agreed to the granting of discretionary power to the SEC to govern the pricing system, but, upon hearing the testimony of Messrs. Bane and Schenker, the industry group decided that the Commission had settled upon a method of regulating pricing and selling which they believed to be "wholly impractical." It It appears that the industry believed the Commission would eliminate the two-price backward pricing system and move to a forward pricing system. ${ }^{51}$ The industry was wliolly opposed to the

45. Id.

46. Id.

47. It is important to distinguish between (1) the effective price advantage secured by distributors, dealers, and some "insiders" as a result of the pricing system formerly in effect and (2) disparities in the actual prices charged to competing ineinbers of the purchasing public, which constitutes "price discrimination" in the generally accepted sense. Although it was the former practice which generated the passage of section 22(d), the section's current function is almost wholly limited to barring the latter.

48. I940 Act Senate Hearings 135-59, 835-63.

49. Id. at 514 .

50. Mr. Traylor stated:

Mr. Schenker had said, because of various problems involved, it seemed desirable early in the consideration of this matter to vest such discretionary power in the S.E.C. rather than attempt to write an inflexible provision into the law. We were generally agreeable to this act at the time, because we felt that the S.E.C. would adopt a practical attitude toward the matter and that between the industry and the S.E.C. a practical solntion to the problems would be found.

Since then, however, the testimony of both Mr. Bane, of the Registration Division, and of Mr. Schenker leaves no doubt in our minds that they have already decided upon a method of pricing and selling shares which we believe to be wholly impractical. Id. at 515 .

51. Mr. Traylor testified:

As I mentioned earlier in this statement, the S.E.C. testimony convinces many of us that they have already decided upon a theory of pricing and selling shares which, we are convinced, would seriously cripple the whole industry. This theory contemplates that shares be sold only on the basis of a price to be determined as at the close of the stock exchange on the day on which purchase orders are executed. Adoption of this theory of selling shares would, in my opinion, be unsound, impractical, and unfair. Id at 523 (einphasis added). 
prospect of forward pricing which could have been (and probably would have been) establislied by the SEC pursuant to section 22(a) as originally drafted. ${ }^{52}$

As to the automatic dilution caused by the normal operation of the two-price system in a rising market, Mr. Traylor pointed out that the loading charge was a deterrent to the average investor's ability to take advantage of the system by moving in and out. He stated:

Incidentally, and I do not think the S.E.C. made this point clear enough in its testimony, the fact that an investor has to pay an underwriting commission or so-called loading charge virtually eliminates even the opportunity in our type of company to buy at one known price and immediately resell at the next higher known price. That is, in buying, the investor pays the asked price, which includes the loading charge of around 7-1/2 percent on the average, and in sell$\mathrm{m} g$ he receives the bid price, which is the asset value of the shares. ${ }^{53}$

This, of course, was true with respect to average investors, but not necessarily true with respect to insiders and dealers.

Mr. Traylor discussed at length the necessity for a "firm" price in the business. ${ }^{54} \mathrm{He}$ suggested that the dilution problem could be solved by establishing a set of rules or regulations, or "some code of fair practice." ${ }^{55}$ In response to a specific question by Senator Wagner on "in-and-out" purchasing, Mr. Traylor remarked that "one of the abuses that occurred was when an insider, so-called, a director or trustee, in a few instances did not have to pay the asked price," and then turned the shares back in the next day. ${ }^{56}$ In an effort to show that the problem was not unsolvable, Mr. Traylor pointed out that under the (then) Blue Sky Law of Ohio, there was a provision which made it necessary for insiders to pay the full asked price and that because of this, the particular dilution abuse would be cured. ${ }^{67}$ The "asked price" Mr. Traylor referred to obviously meant the public offering price, including the sales load, as, opposed to just the net

52. Id. Thus under a forward pricing system, no one, irrespective of whether or not a load was paid, would be able to cause dilution because everyone would pay the net asset value as computed after the order to purchase was received, and they would pay their pro-rata share of that current value in all cases. Furthermore, there would be no opportunity for riskless trading by anyone under such a pricing system.

53. Id. at 522.

54. Mr. Traylor commented that the lack of a "firm price" in the industry would force an increase in selling commissions. His premise was that without a firm price, an incoming shareholder would not be able to purchase the shares at the value during the time he placed the order. Id. at 523-24.

55. Id. at 525.

56. Id. at 526 .

57. Id. 
asset value. In other words, insiders would be kept from moving in and out of the trusts by imposing a load on thein, similar to that which was imposed on ordinary imvestors-thus, largely eliminating the advantage to such rapid trading. Finally, Mr. Traylor made the following comment:

I might say, further, that I use Ohio as an example. But this matter of insider trading the industry wants to cure. It should not have existed; it should not be allowed to exist, and it has been cured insofar as 80 percent of the industry is concerned, by this Ohio regulation, which is a step in the right direction..$^{58}$

Other industry spokesmen continued the attack on the SEC version of the bill giving it power to regulate pricing and selling practices in the industry. Mr. Warren Motley, counsel for Massachusetts Investors Trust, was questioned by Senator Wagner about the problems of dilution. The following exchange took place:

Senator Wagner - . . . It is alleged, and I am entirely dependent upon the testimony, that insiders know that that price tomorrow morning is going to be higher, because they have watched prices go up, I mean prices of different securities that are held. They have that information, and toward the end of the day they buy in a considerable number of shares and therefore have a sure-thing proposition, and they make a so-called insider's profit. Now, if that is possible is there some way by which we can prevent that sort of thing by the inside trader? It does dilute the assets, and to that extent I think it is an injustice to the present shareholders.

Mr. Motley-Senator Wagner, it has been brought out that the outsider, who has to pay a load or selling commission on top of liquidating value, has no incentive or possibility of doing that because the rise in the market in a day would never be nearly enough to let him out with his load. 59

Mr. Motley went on to explain the industry's case for overcoming abuses of dilution and for new, self-regulating provisions in section 22 by again referring to the Ohio regulation requiring a load to be imposed on all sales. ${ }^{60}$

58. Id. at 526-27.

59. Id. at 660 .

60. Mr. Motley continued:

As far as insiders are concerned, the state regulation which has been spoken of as Q3 to which at least 80 percent of the open-end trusts are now subject, now forbids selling shares to anyone except the general distributors and dealers at a price less than the price to the general public. That is why I brought out this point, that the general public cannot take advantage of the situation which you have mentioned. Under the regulation, which I think is a good one, it is forbidden to give a lower price to anyone inside the company. The distributor of course, buys at the flat liquidating value, because he has got to put on the load to pay his expenses and make his profit. The 
Thus appears the real beginning of what became section 22 , including the foundation and rationale for a provision such as section 22(d), which would require a sales load to be imposed on all sales. The sales load requirement was imposed primarily as a deterrent to the value-diluting in-out transactions and "riskless trading" encouraged by the backward-pricing system. The "price-fixing" consequences entailed by the enactment were the mere by-products of the essential scheme. In the above quotation, Mr. Motley presented the case for charging a full load to all persons buying from the fund. This would eliminate, with the exception of principal underwriters and dealers who could be regulated by the industry themselves under the Maloney Act, ${ }^{61}$ any possible dilution abuses. Note, however, that there was absolutely no issue as to price discrimination in the sense that one individual is favored over another because he can obtain something at a lower price. Because the industry did not want to allow the SEC to change the pricing system, i.e., go to a forward pricing system, it advocated an approach to the dilution problem (as ultimately adopted in section 22) which would permit the industry to use self-regulatory procedures to prevent the dilution abuses, and it suggested that a provision imposing the load upon all people would eliminate insider trading. Again, there is no discussion in any of this regarding distribution of mutual fund shares to the public (except insofar as originally proposed sections 22(a) and (b) would apply) or bootleg operations or price discrimination.

In later testimony before the Senate, the SEC, through Mr. Bane, further emphasized the problems of dilution caused by the normal operation of the backward pricing system in conjunction with the

dealer to whom the distributor sells in turn pays a price somewhere between the price which the distributor pays and the price which the public pays.

There is the theoretical, perhaps actual, possibility of the distributor or the dealer taking advantage of the situation which you point out. In well regulated trusts the distributor is forbidden by his coutract to do that. $\mathrm{He}$ agrees to use his best efforts to prevent any dealer from doing it. That is the situation, however, which we all recognize and which, as Mr. Traylor suggested, we feel could best be regulated under the Maloney Act by reason of the fact that it is a situation which can ouly be availed of by distributors and dealers, all of whom are necessarily members of the association created under the Maloney Act. Id. at 661 .

61. The Maloney Act, Act of Juue 25, 1938, ch. 677, $\S 1,52$ Stat. 1070, as amended, 15 U.S.C. \& 780-3 (1970), added \& 15(A) of the 1934 Securities Exchange Act, which provides for self-regulation through registered associations. The NASD is the only associatiou that has ever registered. Mr. Motley did not mention price discrimination in the sense that one individual is favored over another because, by shopping with different brokers, he can obtain a lower sales load, and therefore a better price. The indnstry representatives maintained that their own self-policing techniques had already accomplished the result inteuded, i.e., keeping insiders and others from "rịskleșs ț̣ading" which resulted in dilution, 
load exemptions or discounts enjoyed by some dealers and insiders: ${ }^{22}$

In most of these trusts, the insider and dealer does not have to pay the full load, but buys at a figure close to net asset value. Large purchasers often have the same advantage. If the market appreciation is in excess of the charge to such persons, they have a trading advantage not available to the general public who bear the full load. ${ }^{63}$

Mr. Bane then imtroduced a letter from the vice president of Massachusetts Distributors addressed to the SEC. The letter had been written, after Messrs. Traylor and Motley gave their original testimony, in reponse to a request by Mr. Bane for "suggestions with regard to rules and regulations which the Securities and Exchange Commission might draw up to govern the pricing and sale of shares of open-end investment funds." 64 The letter stated that there were two separate poimts to be considered in working out a solution to the problem:

(1) The setting up of safeguards through the funds and the distributors to prevent any abuse, such as "riskless trading," of whatever pricing system it adopted as standard practice; and

(2) The effective reduction of so-called "dilution" to a practical minimum.

To control "in-and-out" trading by dealers and insiders, the letter suggested that holding periods be imposed on all sales of shares to such parties. ${ }^{65}$ The requirement that a full load be imposed on all purchasers, including insiders, was rejected because, according to the letter, "forcing 'insiders' to pay sales costs when no such costs are involved does not strike us as sound business practice."

Interestingly, section 30(d) of the Act as proposed in S. 3580 would have imposed a holding period on all officers, directors, or ten percent beneficial owners of open-end and closed-end investment company shares, because it provided that the requirements of section 16 of the Securities Exchange Act of 1934 were to apply to all in-

62. Mr. Bane, recapping his earlier testimony, stated:

I explained that the two-price system was used by practically all openend companies now selling and how, with the redemption provisions, in many instances, it resulted in providing one understanding the system, which few people do, a means for absolutely riskless trading to the detriment and further dilutiou of the trust and that some dealers and some insiders take advantage of it. 1940 Act Senate Hearings 841.

63. Id. at 842 .

64. Id. at 858 .

65. Id. at 859 .

66. Id. 
vestment companies. ${ }^{67}$ As indicated in the above letter, this imposition of a holding period would have eliminated the "in-and-out" trading advantages available to insiders. Instead, the industry apparently persuaded the SEC that the imposition of a uniform sales load would be a more appropriate solution to the problem of insider abuse than the application of section 16(b) to the open-end companies. ${ }^{68}$

Just prior to the conclusion of the hearings, Mr. Arthur Bunker, as a representative of the industry, appeared before the Senate Committee to present the industry's position on changes in the bill. One of the points made by Mr. Bunker was as follows:

19. Distribution, redemption and repurchase of redeemable securities, section 22 of the present bill: These sections have to do primarily with problems of dilution and excessive sales loads. As these are problems affecting distribution and transactions with dealers, all of whom are members of a securities association organized and regulated under the Maloney Act, this section should provide that the rules of such securities association may deal with this subject matter. This section should also provide that no securities issued by an investment company shall be sold to insiders or to anyone other than an underwriter or dealer except on the same terms as are offered to other investors.

Appropriate provisions may be made for mergers. ${ }^{69}$

This same language was imcorporated into the memorandum of agreeinent between the SEC and the industry. ${ }^{70}$ In referring to the "same terms," the industry was probably rejecting the position set forth in the letter from the vice president of Massacliusetts Distributors, which advocated contimued load exemption for insiders. It appears that they had opted to clioose the "Ohio" approach and impose a full load on everyone. This theory is supported by the recommendation in the memorandum of agreement as to section 30 , to wit, that the "short-swing profit" provisions of section 16 of the Securities and Exchange Act be applied only to closed-end companies. ${ }^{71}$ Apparent-

67. S. 3580, 76th Cong., 3d Sess. § 30(d) (1940):

(d) Every person who is directly or indirectly the beneficial owner of more than 10 per centum of any class of outstanding securities (other than short-term paper) of which a registered investment company is the issucr, or who is a director or an officer of such a company, shall be subject to the same duties and liabilities as those imposed upon certain beneficial owners, directors and officers by section 16 of the Securities Exchange Act of 1934.

Section 16(b) of the Exchange Act makes recoverable by an issuer to which the provision is applicable any profits obtained by officers, directors or ten percent beneficial owners as a result of any purchase and sale, or sale and purchase, of the issuing equity securities within any period of six months. 15 U.S.C. $\$ 78 p$ (b) (1970).

68. See note 71 infra and accompanying text.

69. 1940 Act Senate Hearings 1057 (emphasis added).

70. 1940 Act House Hearings 99.

71. The Note at the end of the Memorandum of Agreement states as follows: 
ly, it was decided that the imposition of a sales load on the purchase price for open-end company insiders would be a sufficient deterrent in itself.

The necessity for a provision such as section 22(d), in the context of the dilution abuses which led to the adoption of section 22 itself, arises because of the following: sections 22 (a) and (b) provided for self-regulation of distributors, dealers and salesmen, including the imposition of holding periods as to them and the regulution of their pricing methods; and section 22 (c) provided for SEC rulemaking power to supplement section 22(a). Such regulation would not necessarily cover other insiders of open-end companies; section 30 was amended to apply the duties and liabilities imposed under section 16(b) of the Excliange Act only to officers, directors and 10 percent beneficial owners of closed-end companies; therefore, section 22(d) was necessary to place some form of trading restraint on load fund insiders which would nullify the riskless trading advantage they lad enjoyed under the backward pricing system. That advantage resulted from the insider's ability to purchase at net asset value and redeem the following day or two days later at a higher price, which the pricing system had allowed him to foresee at the time he made his purchase. To eliminate this form of "discrimination," the Act provided for a full load to be imposed on everyone, including insiders. The Act could as well have provided, as was recommended by some and as was enbodied in the original section 30 , for a specific holding period-such as the six-inonth period imposed by section 16(b) of the Exchange Act-or other such safeguards to insure that purcliases were made for investment. Moreover, the Act could have required that a method of forward pricing be established. Instead, a form of retail price inaintenance was imposed, the imitial justification for which lias long since ceased to exist. In view of the complicated language ultimately accepted to accomplish the foregoing purpose, it may be assumed that the industry and the SEC may have concluded that it would be desirable to eliminate problems with "non-contract" dealers through this provision, but there is no clear indication on the public record that this was intended.

In addition provision is to be made applying to closed-end companies Section 16 of the Securities and Exchange Act of 1934 in respect of the liability of directors, etc., for profits made within six months on the purchase and sale of the corporation's securities. Id.

The recommendation was followed and section 30 was amended to make only closed-end companies subject to the restrictions of section 16(b). 15 U.S.C. \& 80a29(f). 


\section{LEgislative History-As LATER INTERPRETED}

Both the SEC and the industry have assisted in the perversion of the legislative history of section 22(d). The Commission's General Counsel, on March 13, 1941, stated that "At least one of the purposes of the requirement of disclosure of the "current offering price' is to prevent . . . discrimination."72 The discrimination to which he was referring concerned a fact situation where it was proposed that the principal underwriter have the option of reducing the sales load for purchases in excess of $\$ 25,000$. Given the "purpose" of section 22(d), it is understandable that the General Counsel would not favor placing this option in the hands of the principal underwriter, since he could use it to permit insiders to purchase at no-load and continue to obtain riskless trading profits. However, the General Counsel did agree that, under section 22(d), varying sales loads could be charged based on the quantity purchased, so long as these charges were uniformly apphied to all investors. Such a position would appear contrary to the legislative purpose of section 22(d), since investors, including insiders, could purchase large quantities of inutual fund shares at a much lower load, if the prospectus so provided, resulting in the same dilution abuses and "in-and-out" trading advantages which had earher been achieved by insiders.

By this time, however, the industry itself had already changed its practices so that most funds were precluding insiders from purchasing, except for investment. ${ }^{73}$ Also, less than a inonth after the statements of the General Counsel referred to above, the SEC approved a proposed revision to the NASD Rules of Fair Practice which provided for twice-daily pricing. ${ }^{74}$ By pricing twice daily, the "price

72. SEC Inv. Co. Act Release No. 89 (March 13, 1941), noted at, 17 C.F.R. pt. 271 (1971). There was a form of "discrimination," as pointed out above, in favor of insiders, but it resulted from the ability of insiders to take advantage of the "backward-pricing" system to achieve riskless profits rather than from a policy of classical "price discrimination" on the part of dealers or underwriters. The General Counsel's argument carried to an extreine would simply inean that if imsider purchases were disclosed in the prospectus as being at no-load, this would satisfy the requirements of Section 22(d).

73. At the time of the passage of the Act, a number of funds had already gone to such a method of governing sales of fund shares to insiders. 1940 Act Senate Hearings 855-56.

74. Proposed Amendment to the Rules of Fair Practice of the NASD, Inc., 9 SEC 38 (1941). Article III, section 26(e) of the NASD, Rules of FAIR PRACTICB (Aug. 1967, Reprint of the Manual), required that two prices be established. The portfolio was to be valued at the close of business of the NYSE, and this price would be in effect until 1:00 p.m. of the following business day. The portfolio was to be valued again at 12:00 noon the following day, and the price from this valuation would 
lag" was reduced, thereby reducing the degree of dilution. Reducing the price lag resulted in shares being purchased at a value more nearly the actual value of the portfolio at the time of purchase, and, except in unusual inarket situations, the price differential between the offering net asset value and the actual net asset value would be small. The emasculation of the two-price system by twice daily pricing, the control of dealers and distributors under sections 22 (a) and (b),$^{75}$ and the industry's self-imposed requirement that purchases of inutual fund shares by insiders be made for investment only ${ }^{76}$ virtually eliminated the problems at which section 22(d) was aimed. Therefore, while the prevention of price discrimination between purchasers (in the typical sense of retail price inaintenance) is not reflected in the written record as a reason or justification for the existence of section 22(d), it is understandable, in light of the statutory language itself and the virtuous sounding ring to the phrase "prevention of price discrimination," that such a reason could materialize as a justification. At least no strong arguments were put forth against such an analysis.

In the years after 1941, the SEC granted a number of exemptions from the provisions of section 22(d). ${ }^{77}$ In general, these exemptions permitted reduced sales loads based on the quantity purchased. $^{78}$ In 1958, the SEC, with the concurrence of the NASD and the industry in general, adopted rule $22 \mathrm{~d}-1 .{ }^{79}$ The rule placed se-

be in effect from 1:00 p.m. until the close of business of the NYSE. This cut the period of time for which there would be a price lag. The SEC's decision contains an excellent discussion of the operation of the two-price system. Section 26(e) was subsequently amended, effective Feb. 8, 1971. NASD, Rules of FaIR PRActice § 26(e) (Jan. 1, 1973 Reprint of the Manual).

75. 15 U.S.C. $\$ 80 \mathrm{a}-22(\mathrm{a})$, (b) (1970).

76. See note 73 supra and accompanying text.

77. See, e.g., Axe Houghton Fund, Inc., SEC Investment Company Act Release No. 1505 (Aug. 17, 1950); Investors Diversified Servs., Inc., SEC Inv. Co. Act Release No. 1504 (Aug. 15, 1950).

78. The initial SEC General Counsel's opinion permittimg "quantity discounts," SEC Inv. Co. Act Release No. 89 (March 13, 1941), permitted discounts for "single investments." This led to the practice in the industry of permitting wide discretion in defining what constituted a "single investment." The industry became concerned because of certain tactics employed in establishing a group for making a "group purchase." Disclosure problems were created since it could not be assured that all inembers of the group would receive a prospectus, and the industry feared the widespread evasion of section 22(d)'s retail price maintenance provision through the "back door."

79. SEC Inv. Co. Act Release No. 2798 (Dec. 2, 1958), 17 C.F.R. $\$ 270.22$ d1 (1972). Comments were first sought by the SEC from the industry. SEC Inv. Co. Act Release No. 2718 (1958). The Commission declared, in adopting rule 22d-1, that the "purposes of the Section are to prevent discrimination among purchasers and to provide for orderly distribution of such shares by preventing their sale at a price less than that fixed in the prospectus." SEC Inv. Co. Act Release No. 2798 (Dec. 2, 1958). 
vere restrictions on the situations in which purchasing groups could obtain exemptions or volume discounts from the uniform sales load. In the course of adopting rule 22d-1, the SEC received numerous comments. These written memoranda contain statements purporting to reveal the purpose or intent of section 22(d). Two of these representations appear below:

National Association of Investment Companies Memorandum:

The purposes of Section 22(d) are to insure (a) that there is no discrimination, as between members of the public, in the prices at which open-end investment company shares are sold; and (b) to provide a regulatory framework for the orderly distribution of such shares. The provisions of the proposed rule, whether interpretative of section 22(d) or exemptive in nature, should be analyzed in terms of the purposes underlying Section 22(d). ${ }^{80}$

National Association of Securities Dealers Preliminary Memorandum:

The Committee believes that the provisions of and policy behind Section 22(d) require that all members of the investing public must be entitled to the same price in purcliasing at the same time an identical number of shares of a particular open-end imvestment company. In other words, it is in the public interest and necessary for the protection of the investing public that no member of the investing public or unrelated group of meinbers of the investınent public be given an advantage price-wise over other members of the investing public. The Committee beheves that Section 22(d) requires this result even though the prospectus might describe a different public offering price for different individuals or segments of the investment public. ${ }^{81}$

In neither document is there any citation as to the authority for these propositions. Nevertheless, they were accepted by the SEC, which paraphrased these statements in the release accompanying the adoption of the rule. ${ }^{82}$

At the time these documents were submitted, dilution problems had been substantially reduced. Therefore, the potential use of section $22(d)$ as a price maintenance device and the subsequently assumed legislative history of the section seemed to dovetail. The industry cited the foregoing unsupported assertions as reflecting the policy rationale of section 22(d), and no one challenged their valid-

80. NAIC Memorandum, June 24, 1958, SEC File No. 57-170-1.

81. Preliminary Memorandum from the NASD to the SEC, August 26, 1957, SEC File No. 57-170-1.

82. SEC Inv. Co. Act Release No. 2798 (Dec. 2, 1958). 
ity. In fact, in later articles, the NAIC and NASD memorandums were cited for authority as to the legislative history of section 22 (d).$^{83}$

The SEC in its Public Policy Study, submitted in 1966 to the House Committee on Interstate and Foreign Commerce, adopted the reasoning of the industry and the article writers to that date. ${ }^{84}$ In the Public Policy Study, the SEC said that the section 22(d) proposal was first suggested by the industry and set forth in a memorandum agreement between the Commission and industry representatives submitted to Congress. ${ }^{85}$ This appears to be correct. The Public Policy Study goes on to say that the "legislative history is silent on the reasons for section 22(d)." 86 As shown above, this is not correct, for there is ample indication in the legislative history of at least a primary objective to curb value dilution of fund shares engendered by riskless trading around the two-price system. The Public Policy Study itself states that the abuses cited in the Investment Trust Study were intended to be eliminated by section 22(d), although the Policy Study chose to emphasize the bootleg operations of non-contract dealers as the chief of those abuses. ${ }^{87}$

Finally, and illustrating the extent to which unsupported stateinents in industry memoranda can create "instant" legislative history, the SEC in January 1972 denied an application for exemption under section 22 (d), in part because it would result in "price discrimination" based on the sales load charged. ${ }^{88}$ The SEC, citing to the language of the 1958 Release adopting rule 22d-1, also cited an article written in 1960 which, in turn, had relied on the unsubstantiated NAIC and $N A S D$ memoranda for authority on the legislative purpose of section 22(d)..$^{89}$

The authors submit that this result was not intended by the drafters of section 22(d). If viewed in terms of its legislative history, section 22(d) is primarily an effort to discourage a form of trading which permitted an advantage to those who were not required to pay a full sales load, causing a dilution of the remaining shareholder interests. A provision such as section 22(d) was originally considered unnecessary in the framers' eyes, since the problems which were

83. See, e.g., Greene, supra note 10, at 371.

84. Public Policy Study 218-19.

85. Id. at 219.

86. Id.

87. Id.

88. Mutual Funds Advisory, Inc., SEC Inv. Co. Act Release No. 6932 (Jan. 12, 1972).

89. Id. at 4, citing Greene, supra note 10 , at 371-73. 
the focus of Congress's corrective efforts could have been eliminated by adopting the "forward pricing" method. ${ }^{90}$ Such a forward-pricing structure might not have had the effect on "non-contract" dealers that was desired by the industry and apparently agreed to by Congress, but there is no support in any of the published hearings for the argument that the policy considerations underlying section 22(d) entailed an intention that all people pay the same price for a given mutual fund share -or that a fixed sales load be imposed on all sales or on all sales of a given quantity of shares. As the Public Policy Study poimts out, an investor who lias decided that he will purchase a particular investinent company share, without the benefit of any sales effort by any salesinan, is required under section 22(d) to pay a sales charge "designed to cover selling efforts that lie does not want, does not need and does not get." Si Similarly, as the SEC report points out, "The retail dealer who seeks to expand the volume of his business in the traditional free enterprise way by selling fund shares at lower prices cannot do so." 92

In late 1968, the SEC, under the authority granted it pursuant to section 22(c) of the Act, adopted rule 22c-1 to require all funds to establish "forward pricing." 93 With the advent of rule 22c-1, any possible forms of dilution based on the "backward pricing" system have been eliminated. In view of this, one can only conclude that soine new rationale for a "broad-brush" application of section 22(d)'s price inaintenance provisions inust be established-one which was not contemplated by the framers of the 1940 Act.

\section{Recent Developments Regarding Section 22(d)}

Recent action in Congress and at the SEC has been aimed at changing the impact of section 22(d). There appears to be some divergence of opinion as to the scope and utility of section 22(d), between and within both bodies.

\section{Congress}

In its Public Policy Study, the SEC had expressed strong feelings in favor of abolishing the retail price maintenance of section 22(d),

90. See note 42 supra and accompanying text.

91. Public Policy Study 221. This argument parallels the argument made by in. dustry representatives, at the time of the enactment of the 1940 Act, where they pointed out the same fiction with respect to charging a full sales load to insiders and thus argued for a "placement" or holding period instead of a retail sales maintenance provision. See note 66 supra and accomparying text.

92. Id.

93. SEC Inv. Co. Act Release No, 5519 (Oct. 16, 1968). 
but had concluded that a maximum sales load ( 5 percent) and SEC authority to vary the statutory maximum would be sufficient to curb any problems created by the operation of section 22(d). ${ }^{94}$ Furthermore, the SEC, in the 1967 hearings before the Senate Banking and Currency Committee on S. 1659 (which embodied the SEC's proposal for a 5 percent load maximum), had advised Congress that it felt compelled to accept industry objections to abolition of section 22(d) and was therefore unwilling to recommend a repeal of that provision. ${ }^{95}$ By March of 1969, the Commission had agreed to support the proposal embodied in S. 34, a substantially amended version of $S$. 1659 , which provided for industry regulation of sales loads with SEC oversight, rather than for a flat statutory load maximum. ${ }^{.6}$ On May 21, 1969, S. 2224, ${ }^{97}$ a refined and subdued version of S. 34 was reported out of the Senate Banking and Currency Committee. The new bill, which resulted in the Investment Company Amendments Act of $1970,{ }^{88}$ left section 22(d) virtually untouched, save for a few minor language changes. The Committee Report stated that they had "considered the possibility of deleting section 22(d) from the Act, but that impressive testimony was given that there had not been sufficient study of the consequences of such an amendment."199 The SEC in the earier hearings before the Committee asserted that, before it could recommend an outright repeal of section 22(d), it would need to make further studies of the economic impact of such a move. ${ }^{100}$ The SEC was requested to prepare such a study, and in November, 1972 it submitted its report to Congress. ${ }^{101}$ This Report is discussed in detail below.

\section{$N A S D$}

The Investment Company Amendments Act of 1970, as signed

94. Public Policy Study 222-23.

95. S. 1659 Hearings 50.

96. Hearings on S. 34 and S. 296 Before Senate Comm. on Banking and Currency, 91 st Cong., 1st Sess., 18-19, 29 (1969).

97. S. 2224, 91st Cong., 1st Sess. (1969).

98. See note 102 infra and accompanying text.

99. S. REp. No. 91-184, 91st Cong., 1st Sess. 8 (1969). In this Report, the Senate Committee on Banking and Currency announced that it was requesting the SEC to "review the consequences of such a proposal [repeal of Section 22(d)] on both the investing public and mutual fund sales organizatious and report to it as soon as is reasonably practicable." Id.

100. See note 96 supra.

101. Staff of the SEC, Report on the Potential Economic Impact of a Repeal of Section 22(d) of the Investment Company Act of 1940, (Nov., 1972), reprinted in [1972-73 Transfer Binder] CCH FED. SEG. L. REP. I 79,076 (1972). 
into law on December 14, 1970, left section 22(d) untouched, but authorized registered securities associations (presently only the NASD) to establish rules prohibiting excessive sales loads. ${ }^{102}$ The NASD has prepared and promulgated its study of industry sales loads. ${ }^{103}$ The basic conclusions of this study were (1) that any NASD sales cliarge rule should not prescribe a particular formula; and (2) that the NASD should promulgate rules which reflect consideration of four standards of reasonableness relating to:
(1) Effective competition
(2) Value of service
(3) Salesman's compensation
(4) Cost of distribution

As a result of this study, the NASD in November, 1972 promulgated proposed rules establishing maximum sales charges on the sale of mutual fund shares and variable annuities. ${ }^{104}$ Basically, under the mutual fund sales charge limitations, a fund would be limited to a maximum sales cliarge of 6 percent unless it offered three specified services which themselves would, in the aggregate, carry an additional $21 / 2$ percentage point value as indicated:

(1) Reinvestment of dividends at net asset value (1 $1 / 4)$.

(2) Rights of accumulation ( $1 / 2)$.

(3) Quantity discounts on single purchases (3/4).

If the above three services were offered by a fund, it could establish a sales load of 8.5 percent. Adoption of some but not all of these services would put the sales load limitation at somewhere between 6 and 8.5 percent, depending on the service(s) offered. In addition, the NASD announced at the same time a proposal for limiting sales charges for variable annuity contracts. ${ }^{105}$

Strictly speaking, the NASD's proposals are not appropriate topics for analysis in an article which deals with section 22(d), since the proposals would not alter the basic price maintenance scheme but simply place limitations on the uniform prices which can be charged. However, there seems to be a tendency to associate retail price maintenance with high sales loads and concomitantly to prescribe limita-

102. Investment Company Amendments Act of 1970, Pub. L. No. 91-547, \& 12(c), 84 Stat. 1413, 1423.

103. NASD, Economic Study of the Distribution of Mutual Funds and Variable Annuities (1972), summarized at 2 CCH Mutual Funds GuIDE ๆ 9465 (1972).

104. NASD Release No. 11,172, reprinted at 2 CCH MUTUAL Funds GUIDE If 9571 (Nov. 8, 1972).

105. Id. at 12,162 . 
tions on sales loads as a remedy to the effects of section $22(\mathrm{~d}) .{ }^{106}$ The more recent section 22(d) report of the Commission ${ }^{107}$ indicates that removal of section 22(d) would not necessarily reduce sales loads, so that proponents of the repeal of section 22(d) should not consider that these proposed Rules would be superfluous if, in fact, section 22(d) is repealed.

The NASD's proposals are apparently framed with an intention of overcoming the basic objections to section 22(d), while at the same time retaining some form of its price mamtenance structure. The principal thrust of the proposals is to reject a market structure where the price outcome would be dependent upon competitiveness (as would be the case if section 22(d) were eliminated) and to recommend a market structure where the price outcome would be based on a cost-benefit analysis. The apparent theory behind this approach is that the open market theory of supply and demand is not valid where, as in the mutual fund industry, the demand is "supply-oriented." This approach is a variation on the concept tliat "mutual fund shares are sold, not bought." According to this theory a straight reduction in sales charges resulting from the entry of non-contract cut-price dealers into the marketplace would actually tend to reduce demand, since supply would be reduced as a result of the contract dealers' reluctance to devote any time to the sales effort. Arguably, the ultimate result of this cycle would be that the non-contract dealers, having driven contract dealers out of the marketplace, would cause funds to enter a net redemption stage as a result of the lack of sales. Presumably, if one of the reasons for adopting section 22(d), even if not the primary reason, were to preclude the cut-throat aspects of a secondary market supported by noncontract dealers, and if the NASD's prognosis is correct, then the continued prohibition of price competition from non-contract dealers would be a justifiable reason for retaining at least some of the elements of section 22(d). But there remains the question of whether contract dealers should be permitted to sell inutual fund sliares at varying sales loads, while at the same time being precluded from establishing a secondary market which would tend to have the same attributes as the "bootleg" market mentioned in the Investment Trust Study.

$S E C$

In 1967 and 1968, the prevailing atnosphere at the Commission

106. See text accompanying notes 103-04 supra.

107. Section 22(d) Report, supra note 101, at vi. 
reflected a desire to weaken the effect of section 22(d). Congress was asked by Commission spokesmen to establish a maximum sales load of 5 percent and to give the Commission the power to "vary the statutory maximum by rule or regulation." 108 The Commission itself appeared to be attempting a partial repeal of the retail sales price maintenance provisions through its rulemaking power. In October of 1968, the Commission proposed an anendment to rule $22 \mathrm{~d}-1^{109}$ to delete the prohibition on group purchases for the purpose of obtaining quantity discounts. By using the definition of "person" in section 2(a)(27) of the 1940 Act, the proposed amendment would expand the availability of group discounts to "any organized group of persons whether incorporated or not" and would apparently permit the aggregation of unrelated purchases by unrelated persons who are "organized" purely for the purposes of receiving a discounted price on the mutual fund shares. This proposed ainendınent cane under attack from some quarters, ${ }^{110}$ and apparently the Commission itself has some serious doubts about its wisdoun, since no further action has been taken, and it remains a "proposed" amendinent.

A further indication of the Commission's attitude with respect to section 22(d), subsequent to the promulgation of the above release, appeared in the form of exemptions to individual funds, their principal underwriters, and affiliated companies from the provisions of section 22(d). In 1969, Transainerica Capital Fund was granted an exemption from section 22(d) and permitted to sell its shares, for investment, at no load to regular einployees of the corporations within the conglomerate structure of Transainerica Corporation. ${ }^{111}$ This exeinption apparently was applicable to some 23,000 persons. ${ }^{112}$

Once the barriers had been broken by the Transainerica Release, the Commission began granting further requests for sales load exemptions to other mutual funds, their primcipal underwriters and affiliates. ${ }^{113}$ The NASD objected to these exemptions when the Travelers Corporation filed a request similar to the Transainerica re-

108. However, Chairman Cohen, in hearings during 1967, indicated a willingness to accept NASD regulation of sales loads, provided that the Senate Committee made it "perfectly clear in its reports that it expects the NASD to undertake this responsibility and to carry it out vigorously and expeditiously." S. 1659 Hearings 46.

109. SEC Inv. Co. Act Release No. 5507 (Oct. 7, 1968).

110. See, e.g., Simpson \& Hodes, supra note 10, at 724-28.

111. SEC Inv. Co. Act Release No. 5751 (1969).

112. $1 d$.

113. See, e.g., SEC Inv. Co. Act Releases Nos. 5793 and 5794 (1969), granting exemption orders uuder section 22(d) to Fidelity Trend Fund, Inc. and Puritan Fund, Inc. 
quest. ${ }^{114}$ Aftcr some mimor changes in the structure of the request, however, the order was granted with the blessings of the NASD..$^{115}$

The SEC continued to grant similar exemption orders, but with an added condition in the final paragraph. The orders would normally grant the exemption from section 22(d) which had been requested, subject to the following condition:

That if in the future the Commission amends Rule 22d-1 to change the circumstances under which sales charges may be reduced or eliminated in a manner more restrictive than the circumstances permitted by this order, then on the effective date of such amendment the exemptions granted by this order shall be automatically terminated, and the Rule as amended shall apply. ${ }^{116}$

The language of the preceding condition hinted at a possible change in Commission attitudes, at least with respect to the application of section 22(d) under certain circumstances. The rationale for granting the exemptions froin the uniform load requirements to companies affiliated with the investment manager or principal underwriter of the fund was based on an extension of the application of rule $22 \mathrm{~d}-1(\mathrm{~h})$ providing for reduced or no-load sales in the following situation:

(h) Upon the sale, pursuant to a uniform offer described in the prospectus, to the directors, officers or partners of the investment company, its investment adviser or principal underwriter, or to the bona fide, full-time einployees or sales representatives of any of the foregoing who have acted as such for not less than 90 days, or to any trust, pension, profit-sharing or other benefit plan for such persons, provided that such sales are made upon written assurance of the purchaser that the purchase is made for investment purposes, and that the securities will not be resold except through redemption or repurchase by or on behalf of the issuer. ${ }^{117}$

The Commission then took action to implement the "condition" imposed upon those granted exemptions from section 22(d). In a release issued on February 8, 1971, the Commission adopted an amendment to rule $22 \mathrm{~d}-1(\mathrm{~h})$ restricting the apphicability of the pro-

114. SEC Inv. Co. Act Release No. 5791 (1969), by which the SEC "noticed" the application for exemption filed by Travelers Equities Fund, Inc. A request for hearing was filed by the NASD on October 1, 1969.

115. SEC Inv. Co. Act Release No. 5948 (1969).

116. See, e.g., SEC Inv. Co. Act Releases Nos. 5963 and 6009 (1970), granting exemption orders to First Fund of Virginia, Inc., and Lincoln National Capital Fund and Lincoln National Balanced Fund, respectively.

117. 1940 Act rule 22d-1(h), 17 C.F.R. $\$ 270.22 d-1^{\prime}(h)$ (1972). 
visions of rule 22d-1(h).118 The effect of the amendment was to reduce the class of persons eligible for discount or no-load sales under the rule to those who devote at least one-half of their working time actually performing certain services for the mutual fund or its investment advisers. The Commission decided that it would be appropriate to limit the applicability of the rule $^{119}$ for the following reason:

In view of the proliferation of insurance companies and conglomerate complexes in the investment company industry and the many thousands of employees and other persons who would be entitled to special treatment if the Commission continued to grant exemptive orders in this area, the Commission has reconsidered its position and believes that it is desirable at this time to restrict the class of persons eligible for reduced or eliminated sales cliarges under Rule 22d-1(h). ${ }^{120}$

In a recent application for exemption from the provisions of section 22(d), filed by Mutual Funds Advisory, Inc. (MFA), prior to the release of the Commission's Section 22(d) Report, the Commission continued to express a restrictive view of rule $22 \mathrm{~d}-1 .^{121}$ MFA proposed an arrangement under which it would buy shares of load mutual funds and sell thein to an affiliated fund (Fundpack) at MFA's cost. Fundpack was to be a fund lolding company. Sales to Fundpack would be at net asset value plus that portion of the sales load allocable to the selling fund's principal underwriter. Since MFA would not be selling the shares to Fundpack at the public offering price described in the prospectuses of the mutual funds selling to MFA, MFA requested an exemption from the provisions of section 22(d) to permit it to sell these shares at other than the public offering price. The Commission, as indicated above, ${ }^{122}$ denied the exemption, relymg im support of its demial on doubtful secondary sources for the supposed legislative purpose behind section $22(\mathrm{~d}) .^{123}$ It has been suggested that had MFA's application been filed after completion of the SEC's Section 22(d) Report, the result might have been different. ${ }^{124}$

The Commission's report to Congress on the repeal of section 22(d) appears to bring it full circle back to favoring repeal. While

118. SEC Inv. Co. Act Release No. 6347 (Feb. 8, 1971).

119. Id. See note 7 supra for the details of the rule.

120. Id.

121. SEC Inv. Co. Act Release No. 6932 (Jan. 12, 1972).

122. See notes 88-89 supra.

123. SEC Inv. Co. Act Release No. 6932, at 4 n.7 (Jan. 12, 1972).

124. Hodes, supra note 3, at 1072. 
then Chairman Casey's cover letter to Congress stated that the Section 22(d) Report consists of an "analytical study that makes no recommendations for legislative or administrative action," his letter goes on to say that the "findings (of the study) certainly suggest there is no compelling public interest in continued retail price maintenance" and that "the repeal of section 22(d) would on balance be desirable."125 The Report's conclusions were as follows:

\section{(1) Impact on investors:}

Repeal of section 22(d) would result in lower acquisition costs generally, but not necessarily for the smaller investors and perliaps not at all insofar as the cost of shares issued through so-called "captive organizations."

(2) Impact on mutual fund sales organizations:

Repeal of section 22(d) would have little or no effect on captive sales organizations or distribution of no-load funds. Almost the entire econormic impact would fall on independent broker-dealers who made three-fourths of all load fund sales in 1970 .

(3) Impact on salesmen:

Repeal of section 22(d) would liave little impact on full-time securities salesmen.

(4) Impact on investment company industry:

It is doubtful that repeal of section 22(d) would lead to extensive industrywide net redemptions and any secondary markets which might arise would not necessarily create adverse consequences.

(5) Impact on the capital markets and the economy:

According to the Report, "reductions in mutual fund selling compensation would have no significant impact on the stock market or the economy."126

Thus, according to the Commission, the impact of repeal of section 22(d) would fall almost exclusively on independent brokerdealers-hardly the class that the section was enacted to protect.

The SEC recently completed hearings designed to elicit the economic information which the Commission's 1972 Report suggested was necessary to a fuller understanding of the repercussions which repeal of section 22(d) would generate within the industry. In the announcement of the liearings schedule, the Commission indicated that it would consider as to section 22(d), inter alia, the issues of com-

125. Section 22(d) Report, supra note 101, at vi.

126. Id. at iii-x. 
plete repeal, partial repeal, price competition within a limited range, permitting different "public offering prices" to be described in the prospectus, and prohibiting price competition from non-contract dealers. $^{127}$ To date, no additional reports lave been published by the Commission with respect to the inforination obtained through these hearings, but former (and then) Chairman Cook recently stated that the Commission's analysis should be complete by the summer of $1973 .{ }^{128}$

\section{Antitrust Repercussions}

In recent months, the most significant developments concerning section 22(d) have been the filing of class action civil antitrust suits and a subsequent Justice Department suit against certain inutual funds, their advisory organizations, their principal underwriters, certain broker-dealers, and the NASD, for alleged violations of the antitrust laws in connection with the distribution of mutual fund shares. In the class action suits, the basic claim is that section 22 (d) does not inpose a limitation on the selling price of fund shares in transactions through a broker, but only specifies that the public offering price must be the price at which a dealer offers the shares. Thus, brokers offering shares of a given mutual fund are not precluded, according to the complaint, from matching the purchase and sale orders of two investors represented by the broker on an agency basis. ${ }^{120}$ The Justice Department's suit alleged the existence of a conspiracy to deprive investors of the benefits of a competitive secondary market in fund shares. The Justice Department did not limit itself to the argument made in the class action regarding "matching" sales of purchases by brokers, but claimed that the defendants had prevented a secondary market from being established among dealers because contractual arrangements (and NASD rules) precluded a dealer from selling to or purchasing from another dealer. This not only prevented the establishment of a secondary market, but also, according to the complaint, kept non-contract broker-dealers from purchasing and selling the particular funds. ${ }^{130}$

127. SEC Inv. Co. Act Release No. 7475 (Nov. 3, 1972).

128. Address by Chairman Cook before Investment Company Institute, May 10, 1973, summarized in SEC News Digest No. 73-92, at 1 (May 11, 1973).

129. Haddad v. Crosby Corp., Civil Action No. 2454-72 (D.D.C., filed Dec. 1972), complaint summarized at $2 \mathrm{CCH}$ MUTUAI FUNDS GUIDE $\llbracket$ 9605. See also Groso v. NASD, Civil Action No. 426-73 (D.D.C., filed Mar. 1973), complaint summarized at 2 CCH MUTUAL FUNDS GUIDE \ 9642 (1973).

130. United States v. NASD, Civil Action No. 338-73 (D.D.C., filed Feb. 21, 1973), complaint reprinted at 2 CCH MUTUAL FUNDS GUIDE $\llbracket 9628$ (1973). 


\section{CONCLUSION}

Permissible resale price maintenance arrangements in our economic system are an exception to the general rule of allowing competition to establish price levels. Where resale price maintenance is permitted, such as under state fair trade laws, there usually has been a clear and thorough legislative consideration given the matter before permitting such arrangements to exist. In other instances, such as in the case of commission rates for stock exchanges, ${ }^{131}$ agencies eharged with licensing or other regulatory authorities have been obligated to consider antitrnst principles, along with the other legitimate competing interests of the industry and the public. ${ }^{132}$ Normally, the pros and cons of such anti-competitive devices are considered either by Congress, or the agency involved, in light of the potential antitrust imphications. Section 22(d) operates as a resale price maintenance provision, yet it was given only cursory consideration as to its overall impact on sales competitiveness. It is a provision adopted to eliminate a trading problem wholly unrelated to any concepts of price discrimination, and without apparent consideration of its anticompetitive nature. There may well be valid and legitimate reasons for continuing the retail price structure imposed by the section, but it cannot be asserted that such reasons are to be found in the Act's legislative history, which reveals an intent to solve the problem of dilution of mutual fund assets.

Any legislative or administrative action taken im this area, however, must consider that the mutual fund business has accommodated itself to section 22 (d). If the slate were clean, there might be no economic justification which could support such a sweeping exception to the antitrust laws; but the continued vitality of the huge mutual fund industry, if truly dependent upon such a pricing structure, may dictate the continued existence of at least soine form of price maintenance. ${ }^{133}$ The Economic Report of the President for 1970 contains a comment which appears particularly relevant to the consideration of section $22(\mathrm{~d})$ in

131. The SEC, in section 19(b)(9) of the Securities Exchange Act of 1934, is vested with authority to alter or supplement the rules of a stock exchange with respect to "the fixing of reasonable rates of commission, interest, listing, and other charges. . . ."15 U.S.C. \& 78s(b)(9) (1970).

132. See, e.g., Gulf State Util. Co. v. FPC, 411 U.S. 747 (1973); Silver v. NYSE, 373 U.S. $341,359-60$ (1963).

133. The hearings in the Senate and House on S. 34 and S. 1659 , see text accompanying notes 95-96 supra, contain strong industry testimonials as to the need for retail price inaintenance in sale of mutual fund shares. See, e.g., Report to the Board of Governors of the NASD on Economic Consequences for the Securities and Exchange Commission in its Report to Congress Entitled "Public Policy Implications of Investment Company Growth," S. 1659 Hearings 578. 
light of its legislative history and purpose:

Sometimes regulations created to protect the public against malpractices are extended and used to restrict new entry into a market. Regulations also often prescribe or support minimum or maximum prices. The Investment Company Act of 1940 in effect establishes a resale price maintenance law for mutual funds that prevents retail dealers of inutual funds from charging lower commissions. . . . The problem is to make certain that "fairness" in setting rates does not put an umbrella over inefficiency, and that "soundness" in financial institutions does not become a pretext for impeding competition and innovation. ${ }^{134}$

There would seem to be two possibilities under the circumstances:

(1) Repeal section 22(d) and replace it with a provision designed to safeguard the distribution of mutual fund shares through contract dealers. Maximum sales loads would continue to be applied either under the NASD's cost-benefit analysis or something comparable to it. Shares could only be purchased to fill orders already received, and a secondary market would be precluded. While such a limited repeal of section 22(d) might not create the type of competition among dealers which would result from a complete repeal, it would give mutual funds, their principal underwriters and individual contract dealers more flexibility im the marketing of their shares while preserving the basic distribution structure. Balanced against this position are the argnments that such a repeal would probably not result in a reduction of sales charges to small investors and that, presumably because of the effect as to larger investors, it would weaken the entire industry by driving the small retail dealers away from mutual funds and into other products having a higher sales load.

(2) Retaim section 22(d) but apply it with the liberality deserving of its history. As an initial move in that direction, relaxation of SEC rules on group sales in line with the proposed amendment of rule 22d-1 would seem appropriate. Moreover, consistent with the NASD's view that the price of fund shares should reflect a cost-benefit analysis as well as some consideration of the amount of time and effort going into the sales process, where a mutual fund and its principal underwriter can demonstrate reduced sales expense or reduced benefits made available, then a reduced sales cost would seem appropriate. In cases such as these, the Commission should not feel obliged to adhere to a strict application of section 22(d) because of considerations of price discrimination, since such considerations were never intended to be controlling in the interpretation of section 22(d).

134. Annual Report of the Council of Economic Advisers 101-03 (Jan. 29, 1970). 